advance information supplied by Mr. Barker, with Prof. von Fedorow's kind permission, in the writer's "Crystallography and Practical Crystal Measurement" (Macmillan and Co., Ltd., I9II), the account now definitely published in German requiring nothing to be corrected in that forecast.

A. E. H. Tutrox.

\section{MALARIA IN INDIA.}

THE fourth number of Paludism (Proceedings 1 of the Committee for the Study of Malaria in India), published last March, begins with an interesting account of the proceedings of the second meeting of the general Malaria Committee held in Bombay on November r6-17, I9II. This meeting appears to have been of a very important nature. The president was the Hon. SurgeonGeneral Sir Charles Lukis, C.S.I., the new Director-General of the Indian Medical Service, and his introductory address is well worth the close attention of all sanitarians in tropical countries. After some preliminary remarks, he proceeded to say that he viewed with concern the tendency amongst malaria workers to divide into two camps, namely, those who advocate antimosquito measures, and those who pin their faith on quinine prophylaxis. He directed attention to a previous speech of his, in which he said that-

" whilst agreeing that quinine prophylaxis, properly carried out, was one of the most valuable weapons in the fight against malaria, and whilst admitting that in rural areas it might be the only weapon at the disposal of Government, I felt bound to express my opinion that, if they were to place sole reliance on this measure in Indian villages, they were doomed to disappointment. Quinine prophylaxis should go hand in hand with general sanitation and with the destruction of anopheles breeding grounds wherever this can be accomplished at reasonable expense, and it seems to me that recent observations justify us in thinking that this destruction is not likely to be as costly as has hitherto been supposed. Quinine has undoubtedly conferred inestimable benefits upon the individual; but it never has, and never will, be of equal value to the community as a whole, and you cannot get away from the fact that if there were no mosquitoes there could be no malaria. I fully realise that in some of the hyperendemic areas mosquito destruction may be a counsel of perfection, but even there much good may be done by reducing the numbers of the special species which acts as the carrier, and, I ask you, should we halt in our activity because we cannot attain to an ideal perfection? I recognise the fact that no one method will suffice as a general anti-malarial measure; I recognise the power of each in its proper place, but I hold strong'y that wherever possible anti-mosquito measures must be carried out. I also recognise the importance of preliminary investigation, but it must not be carried to extremes; the time has come for definite action on well-considered and practical lines."

This official pronouncement will be looked upon with gratitude by all those who have been urging the wider policy in India for years past, and will, we hope, prove to be the starting point of a new era. The Director-General proceeded to give some No. 2229 , vol. 89] good advice on many other points; for instance, that actual operations may with advantage be carried out in conjunction with investigation (page 6), and that, indeed, in certain instances the former may be the only method of investigationa point which has long required emphasising. He added that-

"if we wait until our experts have made a complete investigation of all the problems connected with the epidemiology anci endemiology of the disease, there is the danger that India will remain for many years practically untouched. We require then two classes of men-the scientific experts and the practica! workers."

The other proceedings at the Conference showed that this advice is already being largely followed in India. The various provincial organisations for dealing with malaria are described, and several good articles and discussions are given. Both Sir David Semple and Major Robertson (the new Sanitary Commissioner for the Government of India) strongly supported the Director-General's remarks. Captain McKendrick, the Statistical Officer of the Indian Sanitary Department, furnished a very interesting paper on the pathometry of malaria according to the mathematical studies which were discussed by myself and $\mathrm{Mr}$. A. J. Lotka in NATURE of October 5, I9II, and February 8, I912, respectively. Captain McKendrick, who is a capable mathematician, has also added some interesting remarks on the subject, but these cannot be discussed except at some length. References were made to Major Christopher's very interesting researches in the Andaman Islands and to Dr. Bentley's Report on Malaria Prevention in Bombay; and Colonels Dyson and Adie, Majors Wilkinson, Glen Liston, and Robertson, and others added original information on details. I have only one fault to find, and that is that the printing and get-up of Paludism are so very much inferior to the excellence of the matter contained, a fact which may explain why the Director-General has been obliged to ask for more scientific contributions.

Ronald Ross.

\section{THE 250th ANNIVERSARY OF THE ROYAL SOCIETY.}

THE celebrations in connection with the 250 th anniversary of the Royal Society opened on Monday last with an evening reception of the delegates in the rooms of the Society. On Tuesday there was a commemorative service in Westminster Abbey at noon; a formal reception of the delegates and presentation of addresses in the library of the Royal Society in the afternoon, and a banquet in the Guildhall in the evening. Yesterday visits were paid to places of interest in London; a garden-party was given by the Duchess of Northumberland at Syon House and a conversazione was held at Burlington House at night. To-day further visits are being paid to places of interest, and fellows of the Society and the delegates are being entertained by their Majesties 
the King and Queen at a garden-party at Windsor. The following is a list of the delegates from foreign countries and the British Dominions beyond the seas :-

University of Vienna, Prof. F. Exner; Kaiserliche Akademie der Wissenschaften, Vienna, Prof. F. Exner; K.K. Böhmische Karl-Ferdinand University, Prague, Prof. F. Vejdovsky; Kaiserliche Akademie der Wissenschaften, Cracow, Dr. L. Marchlewski; Royal Hungarian University, Budapest, Prof. I. Fröhlich (rector); University of Louvain, Prof. A. de Hemptinne; Académie Royale des Sciences, Brussels, Prof. L. Dollo; University of Copenhagen, Prof. H. F. E. Jurgensen; Kong. Danske Vidensk. Selsk., Copenhagen, Prof. E. Warming; University of Paris, Prof. E. Picard; Faculté des Sciences à la Sorbonne, Paris, M. A. J. F. Dastre; Académie des Sciences de 1'Institut, Paris, M. G. Lippmann (president), Prof. C. Barrois, Prince Roland Bonaparte, M. H. Deslandres, and M. A. Haller; Société Francaise de Physique, Paris, M. E. B. Baillaud; Société Botanique de France, Paris, M. P. de Vilmorin; Société Chimique de France, Paris, M. Hanriot (president); University of Bordeaux, Prof. Pitres; Académie Nationale de Bordeaux, Prof. Pitres; University of Clermont-Ferrand, Prof. Pellet; University of Lille, Prof. A. Schatz; University of Nancy, M. C. Adam (rector); University of Toulouse, Prof. J. Drach; University of Berlin, Prof. IV. Waldeyer and Prof. W. Nernst; University of Bonn, Prof. H. Kayser; University of Breslau, Prof. A. Kneser (rector); University of Erlangen, Prof. Varnhagen; University of Freiburg-im-Breisgau, Prof. O. Bolza; University of Giessen, Prof. W. König; University of Göttingen, Prof. W. Voigt (rector); University of Greifswald, Dr. O. Jaekel; University of Halle, Prof. J. Veit; University of Heidelberg, Prof. G. Quincke; University of Königsberg, Prof. G. Winter; University of Leipzig, Prof. E. Sievers and Prof. W. Ostwald; University of Marburg, Prof. E. Korschelt; University of Munich, Prof. von Groth and Prof. W. C. Röntgen; University of Münster, Prof. K. Busz; University of Rostock, Prof. Rudolf Hübner; University of Strasburg, a representative; University of Tübingen, Prof. von Vöchting; Königl. Preuss. Akad. der Wissenschaften, Berlin, Prof. H. Rubens; Königl. Gesellsch. der Wissenschaften, Göttingen, Prof. O. Wallach; Königl. Bayer. Akad. der Wissenschaften, Munich, Prof. von Groth; University of Athens, Prof. A. Andreades; University of Rome, Prof. V. Volterra; University of Palermo, Prof. G. Guccia; University of Pisa, Prof. R. Nasini; R. Accademia della Crusca, Florence, a representative; R. Istituto Lombardo di Scienze e Lettere, Milan, Prof. V. Volterra; Soc. Reale di Napoli, Sir Archibald Geikie, K.C.B., P.R.S. ; Stazione Zoologica, Naples, Prof. R. Dohrn; R. Accad. dei Lincei, Rome, Prof. M. E. Paternò di Sessa and Conte U. Balzani; Turin, Reale Accad. delle Scienze, Lord Rayleigh, O.M., F.R.S.; Monaco Oceanographical Institute, Mr. J. Y. Buchanan, F.R.S.; University of Amsterdam, Prof. C. Winkler (rector); University of Groningen, Prof. G. C. Nijhoff (rector); University of Leyden, Dr. F. Pijper (rector); University of Utrecht, Dr. A. A. Nyland (rector), Academy of Sciences, Amsterdam, Prof. P. Zeeman (secretary); Hollandsche Maatsch. der Wetensch., Haarlem, Dr. J. P. Lotsy (secretary); Batavian Society, Rotterdam, Dr. R. H. van Dorsten (secretary); University of Christiania, Prof. W. Brögger; Academy of Sciences of Christiania, Prof. H. Mohn (president); Academy of Sciences of Portugal, Lisbon, Mr. E. Prestage; Acad. Impériale des Sciences, St. Petersburg, Dr. O. Backlund, Prince B. Galitzin, Prof. I. P. Pawlow, and Prof. A. Belopol-

$$
\text { NO. 2229, VOL. 89] }
$$

sky; University of Moscow, Prof. A. P. Goubaroff; University of Dorpat (Juriew), Prof. A. I. Jarock1] University of Warsaw, Prof. P. I. Mitrophanow, University of Finland, Helsingfors, Prof. A. Donner (rector), Société des Sciences, Helsingfors, Prof. J. J. Sederholm; Real Acad. de Ciencias, Madrid, Prof. R. Carracido; University of Lund, Prof. C. W. L. Charlier; University of Stockholm, Baron G. de Geer (prorector); University of Upsala, Prof. G. Mittag Leffler and Prof. A. Gullstrand; Kongliga Svenska Vetenskaps Akademie, Stockholm, Count K. A. H. Mõrner (vice-president); University of Berne, Prof. T. Studer University of Geneva, Prof. E. Naville; Société Helvétique des Sciences Naturelles, Berne, Prof. P. A. Guye (secretary); Eidgenössische Technische Hochschule, Zürich, Prof. P. Weiss; University of Egypt, Cairo, H.H. Prince Ahmed Fouad Pacha (president-rector); Gordon College, Khartoum, Dr. J. Currie (principal); Imperial University, Tokyo, Prof. R. Fujisawa; Imperial University, Kyoto, Prof. J. Yokobori ; University of California, Prof. H. C. Plummer; University of Chicago, Prof. E. B. Frost ; Clark University, Worcester, Prof. A. G. Webster; Columbia University, New York, Dr. N. M. Butler (president); Cornell University, Ithaca, N.Y., Prof. J. H. Comstock; Harvard University, Prof. B. O. Peirce; Johns Hoplkins University, Baltimore, Prof. W. B. Clark; Leland Stanford Junior University, California, Prof. V. L. Kellogg; University of Michigan, Prof. W. H. Hobbs; University of Minnesota, Minneapolis, Dr. A. Hamilton; University of Pennsylvania, Philadelphia, Dr. E. F. Smith (provost); University of Princeton, New Jersey, Prof. J. G. Hibben (president); University of Wisconsin, Prof. C. K. Leith; Yale University, Dr. A. T. Hadley (president); American Academy of Sciences, Boston, Prof. E. H. Hall; Connecticut Academy of Arts and Sciences, Prof. E. W. Brown, F.R.S.; American Mathematical Society, New York, Prof. H. B. Fine (president); American Philosophical Society, Philadelphia, Prof. W. B. Scott (vice-president); Franklin Institute, Philadelphia, Major G. O. Squier; California Academy of Sciences, San Francisco, Mr. J. D. Grant; Carnegie Institution, Washington, Dr. R. S. Woodward (president); National Academy of Sciences, Washington, Dr. A. Hague (secretary); Smithsonian Institution, Washington, Dr. A. Hague; Washington Academy of Sciences, Dr. L. O. Howard; University of Adelaide, Prof. H. Lamb, F.R.S.; University of Melbourne, Prof. H. Laurie; University of Sydney, New South Wales, Prof. T. P. A. Stuart; Royal Society of Tasmania, Hobart, Dr. G. Sprott; Royal Society of Victoria, Melbourne, Mr. H. R. Hogg; Royal Society of New South Wales, Sydney, Mr. C. Hedley; McGill University, Montreal, Dr. W. Peterson (principal); University of Toronto, Mr. R. A. Falconer (president); Queen's University, Kingston, Ontario, Prof. J. Watson; University of New Brunswick, Fredericton, N.B., Dr. C. C. Jones (chancellor); University of Manitoba, Winnipeg, Prof. S. Vincent; University of Ottawa, Rev. Dr. Roy (rector); Royal Society of Canada, Ottawa, Sir Gilbert Parker, M.P.; Nova Scotian Institute of Science, Halifax, N.S., Prof. J. G. MacGregor, F.R.S.; H.H. Maharaj Rana Sir Bhawani Singh, Bahadur of Jhalawar, K.C.S.I., Rajputana; University of Allahabad, Rai Bahadur G. N. Chakravati; University of Bombay, Dr. F. G. Selby (late vice-chancellor); University of Calcutta, Prof. P. C. Ray; University of Madras, Dr. A. C. Mitchell; Asiatic Society of Bengal, Calcutta, Mr. G. H. Tipper (hon. secretary); Mohammedan Anglo-Oriental College of Aligarh, Sir T. Morison, K.C.I.E.; Indian Institute of Science, Dr. M. W. Travers, F.R.S. (director); University of the Cape of Good Hope, Prof. A. H. 
MacKenzie; Natal University College, Pietermaritzburg, the Hon. J. C. D. Wilson; Royal Society of South Africa, Sir David Gill, K.C.B., F.R.S.

Sir Archibald Geikie, P.R.S., in welcoming the delegates at the reception, said, according to The Times, that no more striking proof than was presented by that assembly could be given of the reality and cordiality of that spirit of frank and loyal cooperation which united into one great brotherhood the students of science in every land and in every language. Two hundred and fifty years seemed in some respects no long span of time in the course of human history, but the 250 years across which they looked back that day had been in the history of science a period of momentous importance, crowded with incident, and full of marvellous achievement. When in the earlier decades of the seventeenth century Francis Bacon was so cogently insisting on the necessity of studying nature by the careful observation of facts and the testing of conclusions by experiment he made but slight practical impression in England. The seed which he sowed had not sprung into life until after he had passed away. About the middle of the century, however, the spirit of eager curiosity and inquiry with regard to the world which spread over all civilised countries reached England also. The earnest desire to seek an explanation of familiar phenomena at last induced a remarkable group of men in this country to organise themselves systematically for the prosecution of that experimental philosophy which Bacon had so longed to see pursued.

The society had counted among its fellows some of the great leaders in all branches of natural knowledge. Starting its career with a notable group of physicists and mathematicians, among whom were Robert Boyle and John Wilkins, it ere long welcomed Isaac Newton into its ranks, published his immortal "Principia," and annually elected him as its president for nearly a quarter of a century. The physical sciences had all along been strongly represented here. It seemed but yesterday that James Clerk Maxwell's voice was heard in those rooms, and that Stokes and Kelvin sat in the presidential chair. That the succession of leaders was still well maintained, the presence that day of Lord Rayleigh, Sir William Crookes, Sir Joseph Thomson, Sir Joseph Larmor, and many others amply proved. Nor had the biological sciences been less prominent in the work of the society. From the early days of John Ray down to those of Charles Darwin, Hooker, Huxley, and Lister, every branch of biology had been illustrated and advanced by their fellows.

As science knew no restriction of country or language, the Royal Society had from its earliest beginning cultivated friendly relations with fellowworkers in research all over the world. This confraternity of the commonwealth of science now reached the climax of its manifestation in their experience, when they received delegates from so many countries, who by their presence expressed the sympathy and goodwill of the various institutions which they represented.

In proposing at the banquet the toast of "The Royal Society," the Prime Minister said that the society had not at any time had any direct financial assistance from the Government. For this the Government might be criticised; but he ventured to think the society is to be congratulated. It is not well that science should be a mendicant for State endowment. He did not forget the annual grants for scientific research which are administered by the society; but their administration is not a benefit conferred on the society by the State, but a service cunferred on the State by the society. It would not be possible for anyone to traverse in a few moments the history of the society, or to chronicle the achievements of its fellows without at the same time traversing and chronicling the history of English science itself. There is hardly a year when the roll of the society has not been enriched by a name to which not only we, as Englishmen, but the whole world, is indebted for a share in the slow but steady subjection of nature to the intelligence of man-that process which has been described in Bacon's immortal words, "Natura non nisi perendo vincitur." If we look at the names of Isaac Newton and Locke, Flamsteed and Halley, Sir Hans Sloane, Adam Smith and Grote, Woolaston and Watt, Davy and Faraday, Pringle and Young, or closer to our own time, Darwin, Huxley, Hooker, Herschel, Huggins, Sir Michael Foster, Lord Kelvin, and one whose loss we lamented only a few months ago, perhaps the greatest benefactor in our time of the human race, Lord Lister-the roll contains the names of England's worthiest children in the wide field of work which is comprised in the original project of this foundation. And the Royal Society which honoured them and was honoured by them is remembered when we remember them one and all. It has grown with the growth of England; it has advanced with the advance of science; and it stands now, after 250 years, firmly established in the confidence of the nation and the respect of the world, still faithful, still fruitful in the cause of human progress and human enlightenment.

The president of the Royal Society, replying to the toast, said the society has had from its commencement close relations with the Government. They have never been financial relations. At first the society was very poor and tried hard to get money, and among King Charles's benefits, or his wishes to benefit the society, were the efforts which he made for getting them a larger income. He was sorry to confess that those efforts were entirely unsuccessful. They had from him a college, but two years after he gave it he reclaimed it, and bought it back from them. $\mathrm{He}$ believed that $\mathrm{r}_{300 l}$. was all the money they received from their founder Charles II., who devised a plan whereby the Royal Society should undertake to examine all applications for patents for philosophical and mechanical inventions. There was no record of any payment for the services thus rendered. Fifty years later Queen Anne made a similar regulation, but again they had no record that any money passed, for services rendered, into the coffers of the Roval Society. Since then the relations of the society and the Government have taken a very much wider and closer form. They administer a number of permanent grants from the Government, not for their own use, but for the general gond of science. They are largely charged with the administration of the National Physical Laboratory, and they have to administer also the $4000 l$ a year granted by the Government for the furtherance of scientific research. There are many committees which do not bulk very largely in the public eye, but which cost the society a great deal of time and labour and do excellent service, especially those connected with tropical disease.

Viscount Morley of Blackburn proposed the toast of "Universities at Home and Abroad," and the Archbishon of Canterbury that of "Learned Societies in the Old World and the New."

NO. 2229, VOL. 89] 